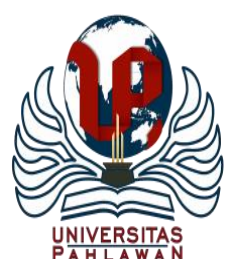

Jurnal Abdidas Volume 2 Nomor 5 Tahun 2021 Halaman 1080-1085

JURNAL ABDIDAS

http://abdidas.org/index.php/abdidas

\title{
Pelatihan Pembuatan Media Pembelajaran Matematika kepada Guru Sekolah Dasar
}

\author{
Siti Quratul Ain ${ }^{1 凶}$, Dea Mustika ${ }^{2}$ \\ Pendidikan Guru Sekolah Dasar, Universitas Islam Riau, Indonesia ${ }^{1,2}$ \\ E-mail : quratulain@edu.uir.ac.id ${ }^{1}$ deamustika@edu.uir.ac.id $^{2}$
}

\begin{abstract}
Abstrak
Kegiatan pengabdian kepada masyarakat ini dilatarbelakangi oleh masih kurangnya pemahaman dan kemampuan guru sekolah dasar dalam pembuatan media pembelajaran matematika. Banyak guru yang masih menggunakan media seadanya. Hal inilah yang mendasari perlunya dilakukan kegiatan pelatihan yang bertujuan untuk meningkatkan keterampilan guru dalam merancang dan mengembangkan media pembelajaran matematika di sekolah dasar. Kegiatan pengabdian pada masyarakat ini dilakukan di SDN 193 Pekanbaru. Metode yang digunakan dibagi menjadi dua tahapan yaitu tahap pertama penyampaian materi dan pendampingan guru yang ingin membuat media pembelajaran matematika di sekolah dasar. Dan tahapan kedua yaitu membuat media pembelajaran sederhana untuk pembelajaran matematika di sekolah dasar. Dengan adanya kegiatan ini dapat memberikan pengetahuan baru bagi guru dalam merancang dan menghasilkan media pembelajaran sederhana yang menarik bagi siswa dalam mencapai tujuan pembelajaran.
\end{abstract}

Kata kunci: media pembelajaran, pembuatan media, guru sekolah dasar

\begin{abstract}
This community service activity is motivated by the lack of understanding and ability of elementary school teachers in making mathematics learning media. Many teachers still use improvised media. This is what underlies the need for training activities that aim to improve the skills of teachers in designing and developing mathematics learning media in elementary schools. This community service activity was carried out at SDN 193 Pekanbaru. The method used is divided into two stages, namely the first stage of delivering material and mentoring teachers who want to make mathematics learning media in elementary schools. And the second stage is making simple learning media for learning mathematics in elementary schools. With this activity, it can provide new knowledge for teachers in designing and producing simple learning media that are attractive to students in achieving learning objectives.
\end{abstract}

Keywords: learning media, media making, elementary school teachers

Copyright (c) 2021 Siti Quratul Ain, Dea Mustika

$\square$ Corresponding author

Address : Jl.Budidaya Ujung perumahan pinang kencana

Email : quratulain@edu.uir.ac.id

ISSN 2721- 9224 (Media Cetak)

DOI : https://doi.org/10.31004/abdidas.v2i5.427

ISSN 2721- 9216 (Media Online) 
1081 Pelatihan Pembuatan Media Pembelajaran Matematika kepada Guru Sekolah Dasar - Siti Quratul Ain, Dea Mustika

DOI: https://doi.org/10.31004/abdidas.v2i5.427

\section{PENDAHULUAN}

Peningkatan kualitas pendidikan menjadi hal penting dalam kemajuan semua bangsa dan menjadi tanggung jawab semua pihak. Pemerintah, swasta, individu dan lain-lain. Oleh karena banyak hal yang harus dilakukan untuk meningkatkan kualitas pendidikan mulai dari strategi yang digunakan dalam pembelajaran, media dan sarana prasarana yang mendukung proses pembelajaran sehingga dapat berjalan dengan efektif. Penggunaan media dalam pengajaran di kelas merupakan sebuah kebutuhan yang tidak dapat diabaikan. Hal ini dapat dipahami mengingat proses belajar yang dialami siswa tertumpu pada berbagai kegiatan menambah ilmu dan wawasan untuk bekal hidup di masa sekarang dan masa akan datang (Umar, 2014).

Peran guru adalah menyediakan, menunjukkan, membimbing dan memotivasi siswa agar mereka dapat berinteraksi dengan berbagai sumber belajar yang ada. Bukan hanya sumber belajar yang berupa orang, melainkan juga sumber-sumber belajar yang lain. Bukan hanya sumber belajar yang sengaja dirancang untuk keperluan belajar, melainkan juga sumber belajar yang telah tersedia. Semua sumber belajar itu dapat kita temukan, kita pilih dan kita manfaatkan sebagai sumber belajar bagi siswa kita.

Wujud interaksi antara siswa dengan sumber belajar dapat bermacam-macam. Cara belajar dengan mendengarkan ceramah dari guru memang merupakan salah satu wujud interaksi tersebut. Namun belajar hanya dengan mendengarkan saja, patut diragukan efektifitasnya. Belajar hanya akan efektif jika pelajar diberikan banyak kesempatan untuk melakukan sesuatu, melalui multimetode dan multimedia. Melalui berbagai metode dan media pembelajaran, siswa akan dapat banyak berinteraksi secara aktif dengan memanfaatkan segala potensi yang dimiliki siswa. Barang kali perlu direnungkan kembali ungkapan populer yang mengatakan: Saya mendengar saya lupa, Saya melihat saya ingat, Saya berbuat maka saya bisa.

Kemajuan teknologi dan informasi menjadi salah satu peluang yang dapat dimanfaatkan guru dalam meningkatkan pola pembelajarannya. Banyaknya perangkat lunak yang tersedia dapat dimanfaatkan untuk mengembangkan media pembelajaran yang lebih interaktif dan menarik minat belajar siswa.

Media pembelajaran adalah segala sesuatu yang dapat digunakan untuk menyalurkan pesan dari guru ke peserta didik sehingga dapat menstimulus pikiran, perasaan, perhatian, dan minat siswa sedemikian rupa sehingga proses belajar mengajar bisa berjalan dengan baik. Media belajar yang dimaksud adalah alat, bahan yang bisa digunakan untuk membantu dalam penyampaian materi pembelajaran (Arsyad, 2010).

Media pembelajaran bisa dipahami sebagai media yang digunakan dalam proses dan tujuan pembelajaran. Pada hakikatnya proses belajar mengajar juga merupakan proses komunikasi, maka media pembelajaran bisa dipahami sebagai media komunikasi yang digunakan dalam proses komunikasi tersebut, media pembelajaran memiliki peranan penting sebagai sarana untuk menyalurkan pesan pembelajaran.

Menurut Anderson (1997) yang dikutip Bambang warsita, (2008) media dapat dibagi 
1082 Pelatihan Pembuatan Media Pembelajaran Matematika kepada Guru Sekolah Dasar - Siti Quratul Ain, Dea Mustika

DOI: https://doi.org/10.31004/abdidas.v2i5.427

menjadi dua kategori, yaitu alat bantu pembelajaran (instructonal aids) dan media pembelajaran (intructional media). Alat bantu pebelajaran atau alat bantu untuk membantu guru dalam memperjelas materi yang akan disampaikan. Oleh karena itu alat bantu pembelajaran disebut juga alat bantu mengajar. Misalnya, OHP/OHT, slide foto, peta, flip chart, model sebenarnya dan sampai kepada lingkungan belajar yang dimanfaatkan untuk memperjelas materi pembelajaran.

Hamalik (1986) yang dikutip Arsyad, (2010) mengemukakan bahwa pemakaian media pembelajaran dalam mengajar dapat membangkitkan keinginan dan minat yang baru, membangkitkan motivasi dan rangsangan kegiatan belajar, dan membawa pengaruh-pengaruh psikologis terhadap siswa.

Empat fungsi media pembelajaran (Sanaky:2009) khususnya media visual yaitu: fungsi atensi, fungsi afektif, fungsi kognitif dan fungsi kompensatoris. Fungsi atensi yaitu menarik dan mengarahkan perhatian siswa untuk berkonsentrasi kepada isi pembelajaran yang berkaitan dengan makna visual yang ditampilkan. Fungsi afektif media visual yaitu dapat terlihat dari tingkat kenikmatan peserta didik ketika belajar atau membaca teks yang bergambar. Fungsi kompensatoris media pembelajaran terlihat dari hasil penelitian bahwa media visual yang memberikan konteks untuk memahami teks membantu siswa yang lemah dalam membaca dan mengorganisasikan informasi dalam teks dan mengingatnya kembali.

Manfaat media pembelajaran dalam proses belajar siswa menurut (Nana Sudjana \& Ahmad Rivai, (2002) yaitu:

1. Pembelajaran akan lebih menarik perhatian siswa sehingga dapat menumbuhkan motivasi belajar

2. Bahan pembelajaran akan lebih jelas maknanya

3. Metode belajar akan lebih bervariasi, tidak semata mata komunikasi verbal

4. Siswa dapat lebih banyak melakukan kegiatan belajar.

Macam-macam media pembelajaran (Hujair, 2009) yaitu media visual, media audio dan media audio visual. Media yang digunakan oleh guru harus relevan dengan materi dan strategi yang digunakan dalam pembelajaran (Gunawan ,2016). Keberadaan media sangatlah penting sehingga media menjadi bagian yang perlu ada dalam proses pembelajaran.

Sekolah Dasar Negeri 193 Kecamatan Marpoyan Damai Kota Pekanbaru memiliki sumber daya yaitu guru-guru yang profesional dibidangnya. Profesionalitas sumber daya di sekolah ini bisa ditingkatkan dengan memaksimalkan potensi melalui pengembangan diri dengan mamanfaatkan sarana yang ada untuk meningkatkan kualitas pembelajaran. Fasilitas internet juga dapat memperkaya konten materi yang dapat disiapkan untuk disampaikan kepada siswa. Pemanfaatan teknologi informasi dapat memperkaya konten materi, sedangkan aplikasi presentasi digunakan untuk mengemas konten yang disiapkan menjadi kesatuan media pembelajaran yang menarik dan berkualitas. Berangkat dari kondisi tersebut, tim pengabdia dari 
1083 Pelatihan Pembuatan Media Pembelajaran Matematika kepada Guru Sekolah Dasar - Siti Quratul Ain, Dea Mustika

DOI: https://doi.org/10.31004/abdidas.v2i5.427

jurusan Pendidikan Guru Sekolah Dasar FKIP Universitas Islam Riau melakukan pengabdian dengan tujuan memberi pelatihan pembuatan media pembelajaran bagi guru disekolah dasar kecamatan Marpoyan Damai, Pekanbaru. Kegiatan ini dimaksud untuk meningkatkan pengetahuan dan pemahaman guru dalam pembuatan media pembelajaran matematika.

\section{METODE}

Kegiatan pengabdian kepada masyarakat ini dilaksanakan di SD Negeri 193 Pekanbaru. Waktu kegiatan pengabdian kepada masyarakat pada bulan Oktober sampai dengan bulan Januari 2020.

Kegiatan dilaksanakan dengan menggunakan pendekatan klasikal dan pendekatan individual. Pendekatan klasikal berupa penyampaian materi dan pendekatan individual berupa pendampingan (Mustika et al, 2021). Prosedur Pelaksanaan Kegiatan pengabdian dapat digambarkan sebagai berikut.

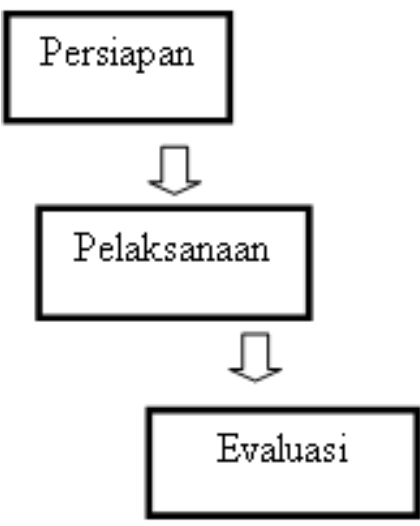

Gambar 1. Prosedur Kegiatan Pengabdian

Pada gambar 1 dapat diamati bahwa prosedur kegiatan pengabdian terdiri dari tiga tahap yaitu : tahap persiapan, tahap pelaksanaan dan tahap evaluasi. Secara rinci uraian kegiatan pengabdian adalah:

1. Memberi penjelasan tentang media pembelajaran matematika di SD.

2. Memberi panduan dan menjelaskan jenis media yang dapat digunakan dalam pembelajaran matematika di SD.

3. Membimbing praktek pembuatan media pembelajaran matematika di SD.

4. Pendampingan peserta oleh dosen kepada guru selama kegiatan pembuatan media pembelajaran matematika di SD.

5. Pelaksanaan penilaian terhadap media pembelajaran matematika di SD.

\section{HASIL DAN PEMBAHASAN}

Pelaksanaan kegiatan pengabdian dimulai dengan dilakukan oberservasi pada pihak SDN 193 Pekanbaru. Observasi lapangan bertujuan untuk mengkomunikasikan izin dan tahapan pelaksanaan kegiatan pada pihak sekolah. Setelah mendapat izin dari pihak sekolah, maka dilakukan kegiatan pengabdian yang dilaksanakan pada tanggal 10 Januari 2020. Hasil dari pelaksanaan kegiatan dapat diuraikan sebagai berikut:

1. Tahap persiapan

Pada tahap persiapan, tim pengabdian mempersiapkan segala perlengkapan diantaranya: persiapan administrasi, koordinasi dengna mitra sasaran, observasi sarana prasarana, persiapan materi pelatihan dan persiapan kelengkapan untuk pembuatan media pembelajaran, penyusunan jadwal pelatihan 
1084 Pelatihan Pembuatan Media Pembelajaran Matematika kepada Guru Sekolah Dasar - Siti Quratul Ain, Dea Mustika

DOI: https://doi.org/10.31004/abdidas.v2i5.427

2. Tahap pelaksanaan

Tahap pelaksanaan bertempat di SD Negeri 193 di kecamatan Marpoyan Damai yang diikuti oleh guru-guru SD Negeri 193 kecamatan Marpoyan Damai. Materi pelatihan disampaikan oleh tim pengabdian dengan materi media pembelajaran Matematika SD yang tepat, macam media pembelajaran, praktek membuat media pembelajaran dan simulasi media yang telah dibuat peserta pengabdian.

3. Tahap evaluasi

Pada tahap evaluasi, tim pengabdian dibagi untuk memeriksa hasil dari pembuatan media pembelajaran matematika. Hasil evaluasi kemudian dijadikan bahan diskusi lanjutan bersama peserta pengabdian untuk mencari tahu hambatan dalam pembuatan media pembelajaran matematika di SD.

Pelaksanaan kegiatan pengabdian kepada guru-guru SD Negeri 193 Kecamatan Marpoyan Damai ini dapat dikatakan berjalan dengan baik. Peserta pengabdian menunjukkan antusiasme dalam pelaksanaan kegiatan. Ini dilihat dari partisipasi yang diberikan selama kegiatan berlangsung. Hasil akhir dari pelaksanaan pelatihan juga mendapat tanggapan positif

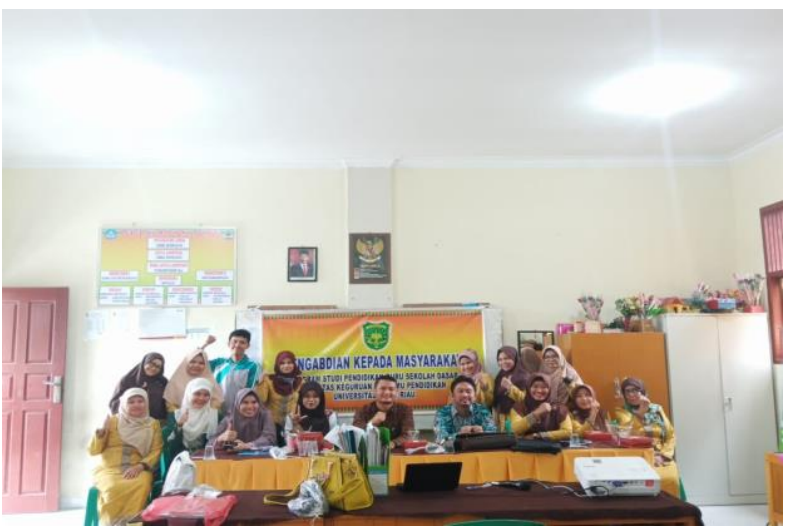

Gambar 2. Sesi dokumentasi tim pengabdian bersama guru SDN 193 Pekanbaru

\section{SIMPULAN}

Kegiatan pengabdian kepada masyarakat ditujukan pada guru sekolah dasar dengan melakukan pelatihan pembuatan media pembelajaran matematika. Kegiatan yang dilaksanakan ini telah berjalan dengan baik mulai dari tahap persiapan hingga tahap evaluasi. Kegiatan ini membantu menambah pengetahuan dan pemahaman guru sekolah dasar tentang mendia pembelajaran yang dapat digunakan pada pembelajaran matematika khususnya. Selain itu guru dapat berlatih membuat media pembelajaran matematika sederhana. Selama kegiatan ini berlangsung, peserta menunjukkan antusiasme dan berharap kegiatan pada masyarakat dapat dilaksanakan berkelanjutan dengan penyampaian materi yang berbeda.

\section{UCAPAN TERIMA KASIH}

Ucapan terima kasih pada LPPM Universitas Islam Riau yang telah mendanai pelaksanaan kegiatan pengabdian kepada pihak SDN 193 Pekanbaru yang telah memberikan izin serta membantu menyediakan tempat pelaksanaan 
1085 Pelatihan Pembuatan Media Pembelajaran Matematika kepada Guru Sekolah Dasar - Siti Quratul Ain, Dea Mustika

DOI: https://doi.org/10.31004/abdidas.v2i5.427

kegiatan selain itu disampaikan terimakasih kepada pihak-pihak yang telah membantu sehingga kegiatan pengabdian ini berjalan dengan baik.

\section{DAFTAR PUSTAKA}

A.H Hujair Sanaky. (2009). Media Pembelajaran. Safira Insania Press.

Azhar, Arsyad. (2010). Media Pembelajaran. PT. Raja Grafindo Persada.

Dea Mustika \& Siti Quratul Ain. (2021). Pelatihan penyusunan artikel ilmiah bagi guru sekolah dasar di Kecamatan Marpoyan Damai Pekanbaru. Rengganis Jurnal Pengabdian Masyarakat, $\quad$ 1(1), 42-47. https://doi.org/10.29303/rengganis.v1i1.16

Gunawan, Imam. (2016). Metode Penelitian Kualitatif. Bumi Aksara.

Nana Sudjana \& Ahmad Rivai. (2002). Media Pengajaran. Sinar Baru Algensindo.

Warsita, Bambang. (2008). Teknologi Pembelajaran Landasan \& Aplikasinya. Rineka Cipta Sanaky 2009. 